\title{
UNIVERSITY OF KIEL RADIOCARBON MEASUREMENTS III
}

\author{
H. WILLKOMM and H. ERLENKEUSER
}

\author{
$\mathrm{C}^{14}$ Laboratory of the University of Kiel, Germany
}

Most of the measurements have been obtained with a 4.5- $\mathrm{L}^{\mathrm{CO}_{2}}$ counter (Kiel I). Dates given are not corrected for $\mathrm{C}^{13} / \mathrm{C}^{12}$ except Ulmus series. Error corresponds to $1 \sigma$ of statistical variations of sample net counting rate including variance of reference and background, but does not include the uncertainty in $\mathrm{C}^{14}$ half-life and in secular $\mathrm{C}^{14}$ variations. Half-life is $5570 \mathrm{yr}$ and A.D. 1950 is zero point of B.P. scale.

\section{ACKNOWLEDGMENTS} analysis.

We thank Dr. J. N. Mathur and Mr. H. Schüler for the $\mathrm{C}^{13} / \mathrm{C}^{12}$

\section{BOMB PRODUCED RADIOCARBON}

To get some more information about the distribution of bomb produced $\mathrm{C}^{14}$, we measured the last 17 tree-rings of an Ulmus cut 1965 in Kiel (54 $19^{\prime} 55^{\prime \prime} \mathrm{N}$ Lat, $10^{\circ} 7^{\prime} 30^{\prime \prime}$ E Long). The $\mathrm{C}^{13} / \mathrm{C}^{12}$ ratio was measured with an Atlas CH4 mass spectrometer against NBS standard oxalic acid which was prepared in the same manner as tree samples. For the oxalic acid we assumed $\delta \mathrm{C}^{13}=-19.3 \%$ (Craig, 1961). In this assumption, there can be a systematic error, which is too small to affect the $\Delta$-values seriously. $\delta \mathrm{C}^{13}$ values in parenthesis were not measured. For calculation of $\Delta$ we used in these cases the mean value $-25.5 \%$.

\begin{tabular}{|c|c|c|c|c|}
\hline Sample & $\begin{array}{l}\begin{array}{l}\text { Year of tree-ring } \\
\text { growth }\end{array} \\
\end{array}$ & $\delta \mathrm{C}^{14} \%$ & $\delta \mathrm{C}^{13} \%$ & $\Delta$ \\
\hline $\overrightarrow{\mathrm{KI}-14 \mathrm{I}} / 1$ & 1964 & $\overrightarrow{908 \pm 15}$ & $\overline{-24.4}$ & $\overline{906 \pm 15}$ \\
\hline KI-141/2 & 1963 & $842 \pm 10$ & $(-25.5)$ & $844 \pm 10$ \\
\hline KI-141/3 & 1962 & $405 \pm 22$ & -25.6 & $407 \pm 22$ \\
\hline KI-141/4 & 1961 & $233 \pm 7$ & -27.0 & $238 \pm 8$ \\
\hline KI-141/5 & 1960 & $253 \pm 9$ & -26.0 & $256 \pm 9$ \\
\hline KI-141/6 & 1959 & $292 \pm 7$ & $(-25.5)$ & $293 \pm 7$ \\
\hline KI-141/7 & 1958 & $171 \pm 6$ & -25.2 & $171 \pm 6$ \\
\hline KI-141/8 & 1957 & $116 \pm 9$ & $(-25.5)$ & $117 \pm 9$ \\
\hline KI-141/9 & 1956 & $26 \pm 10$ & -25.3 & $27 \pm 10$ \\
\hline KI-141/10 & 1955 & $18 \pm 6$ & -24.2 & $16 \pm 6$ \\
\hline KI-141/12 & 1953 & $-6 \pm 7$ & -25.1 & $-6 \pm 7$ \\
\hline KI-141/13 & 1952 & $-5 \pm 9$ & -25.4 & $-4 \pm$ \\
\hline KI-141/14 & 1951 & $-20 \pm 6$ & -26.2 & $-18 \pm$ \\
\hline KI-141/15 & 1950 & $-21 \pm 5$ & -25.5 & $-20 \pm$ \\
\hline KI-141/16 & 1949 & $-37 \pm 5$ & -25.3 & $-36 \pm$ \\
\hline KI-141/17 & 1948 & $-41 \pm 6$ & -26.6 & $-38 \pm$ \\
\hline
\end{tabular}




\section{Dahldorf series}

Peat samples from N part of "Teufelsmoor," $2 \mathrm{~km} \mathrm{SW}$ of Gnarrenburg (53 22.1' N Lat, $8^{\circ}$ 58.7' E Long), Germany. Coll. 1963 and subm. 1965 by F. Overbeck, Botanisches Inst., Univ. Kiel, who also made pollen analysis. Series aids investigation of history of settlement in N Germany. Samples KI-135, KI-136, and KI-137 contained large amounts of rootlets, most of which were removed before chemical treatment. Some dates were listed earlier in Kiel I and Kiel II. The completed series is given now.

\section{KI-23. Dahldorf II-1, $30 \mathrm{~cm}$ depth}

$$
2160 \pm 80
$$

Sphagnum peat from upper part of highly humified peat layer. From this level upward Carpinus exceeds $1 \%$. Fagus is $5 \%$ and more (Kiel I).

\section{KI-133. Dahldorf II-2, $50 \mathrm{~cm}$ depth} $\mathbf{2 5 3 0} \pm \mathbf{5 0}$

Plantago lanceolata, Rumex, Artemisia at minimum show lack of agriculture. No cereal-type pollen found. Fagus at minimum. Corylus is dropped to $10 \%$.

\section{KI-24. Dahldorf II-3, $70 \mathrm{~cm}$ depth}

Maximum of humification. Corylus at 5 to $10 \%$. No agriculture at this time (Kiel I).

\section{KI-135. Dahldorf II-4, $98 \mathrm{~cm}$ depth}

Sample from just above contact between black and light peat.

\section{KI-136. Dahldorf II-5, $100 \mathrm{~cm}$ depth}

$3110 \pm 70$ 1160 в.c.

0 to $1 \mathrm{~cm}$ below contact between dark and light peat, just below 1st indication of cereal-type pollen. Comment: date includes previous measurement (KI-25, Kiel II). KI-135 and KI-136 indicate no great interval of reduced growth rate during change from dark to light peat.

\section{KI-137. Dahldorf II-6, 105 cm depth}

Above this level Fagus is less than $1 \%$.

$$
1100 \text { в.c. }
$$

\section{KI-138. Dahldorf II-7, $130 \mathrm{~cm}$ depth}

Maximum of Corylus (up to $38 \%$ ). Tilia less than $1 \%$. Plantago lanceolata beginning of strong increase (Kiel II).

KI-139. Dahldorf II-8, $187 \mathrm{~cm}$ depth 
KI-140. Dahldorf II-9, $195 \mathrm{~cm}$ depth

From this level upward Plantago curve is continuous and Ulmus is less than $5.2 \%$ (Kiel II).

\section{Esterweger series}

Peat samples from "Esterweger Dose," bog near Burlage (53 $3.2^{\prime}$ $\mathrm{N}$ Lat, $7^{\circ} 34.5^{\prime} \mathrm{E}$ Long, Messtischblatt Burlage Nr. 2911 r 3408680 h 5878340), Germany. Coll. 1963 and subm. 1965 by R. Wiermann, Botanisches Inst., Univ. Münster, Germany. Comment: this series aids investigation of development of vegetation in N Germany and helps date some significant horizons in history of propagation of Fagus (KI-177-179) and Carpinus (KI-175, 176). Other samples give dates of special events in history of agriculture (lack of agriculture) KI-169-170; KI-172; KI-174 and KI-177-179).

KI-169. ED-II, 1, 5.0 to $9.5 \mathrm{~cm}$

KI-170. ED-II, 2, 9.5 to $14.0 \mathrm{~cm}$

KI-172. ED-II, 4, 24.5 to $28.0 \mathrm{~cm}$

KI-173. ED-II, 5, 38.3 to $42.0 \mathrm{~cm}$

KI-174. ED-II, 6, 49.5 to $54.0 \mathrm{~cm}$

KI-175. ED-II, 7, 75 to $80 \mathrm{~cm}$

KI-176. ED-II, 8, 80 to $85 \mathrm{~cm}$

KI-177. ED-II, 9, 85 to $90 \mathrm{~cm}$

KI-178. ED-II, 10, 90 to $95 \mathrm{~cm}$

KI-179. ED-II, 11, 95 to $100 \mathrm{~cm}$

$$
210 \pm 40
$$

A.D. 1740

A.D. 1540

$410 \pm 35$

A.D. 1270

$680 \pm 35$

A.D. 1150

$800 \pm 55$

$1050 \pm 40$

A.D. 900

$1560 \pm 50$

A.D. 390

$1450 \pm 60$ A.D. 500

$1490 \pm 55$

A.D. 460

$1620 \pm 50$

A.D. 330

$1730 \pm 50$

A.D. 220

\section{Kubitzberg}

Peat from Kubitzberger Moor, bog (54 $24^{\prime} \mathrm{N}$ Lat, $10^{\circ} 7^{\prime} \mathrm{E}$ Long), 1 km NW of Altenholz near Kiel, Germany. Coll. by Usinger; subm. 1967 by L. Aletsee and J. Gehl, Botanisches Inst., Univ. Kiel. Samples record development of forests in N Germany. Height difference between samples is $35 \mathrm{~cm}$. 
KI-94. Kub B II - a

$8200 \pm 160$

Maximum of Corylus; 1st Fagus pollen.

6250 B.c.

KI-219. Kub B II - b

$8530 \pm 70$

First increase of Corylus.

6580 B.C.

\section{ARCHAEOLOGIC SAMPLES}

\section{Möllenknob series}

Samples from excavations of "Möllenknob" settlement near Archsum on Sylt island, Schleswig-Holstein ( $54^{\circ} 52.7^{\prime} \mathrm{N}$ Lat, $8^{\circ} 22.5^{\prime}$ E Long, Topographische Karte 1116 Morsum r 3460760 h 6082 360), Germany.

Rural settlement in form of "Tell" at border of sandy moraine ("Geest") to marsh ("Marsch") with 7 phases of late Bronze age to 4th century A.D.

Excavations directed by G. Kossack, Inst. für Ur-und Frühgeschichte, Univ. Kiel. Coll. 1963, 1964 by R. Kenk; subm. 1965 by G. Kossack and F. R. Averdieck, Univ. Kiel. Excavations are being conducted now; a complete treatise on "Möllenknob" is to be published. detail.

Archaeologic dating will not be exact until material is studied in

KI-144. Möllenknob 25, 6

$1650 \pm 35$

Carbonized barleycorns from rubble of burned dwelling house; 100 $\mathrm{cm}$ below surface $(3.90 \mathrm{~m} \mathrm{NN})$; preliminary archaeol. estimate 200-300 A.D.

KI-145. Möllenknob 13, 1

$1910 \pm 45$

Charcoal of Fraxinus root 30 to $40 \mathrm{~cm}$ below surface; archaeol. dated ca. 4th century A.D.

\section{KI-146. Möllenknob 28, 3}

$1920 \pm 60$

Charcoal (Quercus) of house post; $100 \mathrm{~cm}$ below surface; preliminary archaeol. estimate 200-400 A.D.

\section{KI-147. Möllenknob 64, 5}

Wood (Quercus); $150 \mathrm{~cm}$ below surface; preliminary archaeol. estimate $0-200$ A.D.

KI-148. Möllenknob 68, 3

$$
1940 \pm 40
$$

Wood (Alnus) from pile, $160 \mathrm{~m}$ below surface; preliminary archaeol. estimate 0-200 A.D. 
KI-149. Möllenknob 98, 11

Charcoal (Quercus); $120 \mathrm{~cm}$ below surface; supposedly belongs to late Bronze age grave.

KI-150. Möllenknob 101, 4

$1920 \pm 60$

Charcoal (Quercus); $100 \mathrm{~cm}$ below surface; parts of burned house; preliminary archaeol. estimate 0-200 A.D.

KI-151. Möllenknob 123, 5

$1980 \pm 60$

Charcol (Quercus) from rubble of burned dwelling. preliminary archaeol. estimate 200-400 A.D.

KI-74. Möllenknob

$1830 \pm 60$

Wattle and daub in stratum of dung; preliminary archaeol. estimate ca. 2nd century A.D.

General Comment (F.R.A.): there seems to be a systematic difference between $\mathrm{C}^{14}$ dates and archaeologic dates, which cannot be explained by variations of $\mathrm{C}^{14}$ content of atmosphere. Possibly on this island without trees the same wood was used more than once, and therefore was cut long before it reached discovery site.

Cereals and wattle, expected to have grown a short time before their carbonization, give same age as expected archaeologically (KI-144, KI-74).

\section{Dätgen, mummified human body}

Sphagnum cuspidatum peat, Grosses Moor, Dätgen, $\left(54^{\circ} 10 \mathrm{~N}\right.$ Lat, $9^{\circ} 56^{\prime}$ E Long), Germany. Subm. 1966 by L. Aletsee, Botanisches Inst., Univ. Kiel, now at Technische Hochschule Aachen.

\section{KI-86. Dätgen - upper layer}

Peat from hollow mummified body was lying in. According to stratigraphical position peat should give lower age limit. Date given in Kiel I (KI-17, $2065 \pm 90)$ should be upper age limit.

\section{KI-92. Dätgen - medium layer}

$2030 \pm 60$

Third peat sample from another part of hollow. Comment: there is no significant difference among the 3 dates.

\section{REFERENCES}

Date lists:

Kiel I

Willkomm and Erlenkeuser, 1966

Kiel II

Craig, Harmon, 1961, Mass-spectrometer analyses of radiocarbon standards: Radiocarbon, v. 3, p. 1-3. 